\title{
Hydrothermal Alteration Mineralogy Associated with Gold Mineralization in Buladu Area, Gorontalo, Northern Sulawesi, Indonesia
}

\author{
Ulva Ria Irfan", Irzal Nur , Muhammad Kasim \\ ${ }^{\# 1}$ Geological Engineering Study Program of Hasanuddin University, Jl. Poros Malino KM. 60, Gowa, 92171, Indonesia \\ E-mail: ulvairfan@yahoo.com \\ ${ }^{{ }_{2}}$ Mining Engineering Study Program of Hasanuddin University, Jl. Poros Malino KM. 60, Gowa, 92171, Indonesia \\ E-mail: irzal_nur@yahoo.com \\ ${ }^{\#}$ Geographical Education Study Program of Gorontalo State University, Jl. Sudirman No.6, Gorontalo, 96128, Indonesia \\ E-mail:muhkasim@ung.ac.id
}

\begin{abstract}
Geologically, the Buladu area is part of the North Sulawesi magmatic arc, located in the morphology of the mountains along the coastline of North Gorontalo district, Indonesia. Multiple subductions of North Sulawesi in the northern arm of Sulawesi and east Sangihe subduction in the east has triggered an active magmatism and volcanism. Formation and occurrences deposits of precious- and base metals have been found in the North Sulawesi Volcanic Arc. This paper describes a recent study on hydrothermal alteration mineralogy associated with one of the prospects in the region, namely Buladu gold prospect that for years has been operated by local artisanal miners. The study is focused on hand specimen and microscopic observation as well as XRD analysis. Lithologically, the study area is arranged by sandstone are members of Dolokapa volcano-sedimentary formation, above unconformity andesitic-basaltic volcanic breccia are members of the Pliocene Wobudu Formation and is intruded by granodiorite rocks. The petrographic study reveals that host rock of the mineralization is flow-volcanic breccia which shows porphyritic and flows structures. Resulting assemblages of secondary minerals are mineral associations characteristic of the magmatic-hydrothermal system the following imperative alteration zones could be recognized an outer zone of chloritic alteration and the inner zone of argillic alteration. The alteration showed characteristics of pervasive to selective alteration, where clay and quartz totally replaced groundmass, whereas chlorite and clay minerals were selectively altered plagioclase phenocrysts. Clay mineral species identified by XRD include chlorite and illite. These mineralogical features indicate that the hydrothermal alteration is an argillic type, which is spatially distal to the mineralization. Mafic mineral in andesite lava partly altered into mineral assemblage chlorite-epidote-quartzcarbonate show propylitic type, which is the outermost zone of mineralization.
\end{abstract}

Keywords - hydrothermal; alteration; mineralogy; gold; Buladu.

\section{INTRODUCTION}

Geographically, the Northern Arm of Sulawesi extends from the neck of Sulawesi Island to the North Sulawesi Arc [1]. The North Sulawesi Arc is a volcanic arc which developed related to multiple subductions of north Sulawesi subduction in the northern arm of Sulawesi and east Sangihe subduction in the east [2]. These multiple subductions have triggered an active magmatism and volcanism that produced some plutonic rocks and young volcanic cones [3], [4], [5]. Therefore, the sequence of rocks which form the northern Sulawesi can be divided into three groups separated by a regional unconformity.
North Sulawesi subduction assumed active since the beginning of the Tertiary and produced Tertiary volcanic arc extending from Toli-Toli to Gorontalo until near Manado, which is also referred to as old volcanic arcs. Rock group consists of a series of rocks of Middle Eocene-Late Miocene volcanic arc oceanic submarine, named Papayato Volcanic [6], [7]. This unit consists of a series of basaltic volcanic that occur in bimodal association with much less voluminous felsic rocks. The basaltic volcanic include massive, auto brecciated or pillowed lava flows, and volcanic breccia [7].

The Mid-Cenozoic group consists of a predominantly Bilungala Volcanics, a mixed Dolokopa Formation, and several sedimentary units, including the Ratatotok 
Limestone, which hosts Mesel and associated gold deposits. The volcanic rocks consist of andesitic lava flows and pyroclastics, debris flows, and related volcaniclastics. This is marking multiple periods of uplift and erosion during the development of the mid-Cenozoic volcanic arc [8].

The Late Cenozoic observed widespread and intensive volcanism, which was the most productive mineralizing period. The Early Pliocene Wobudu Breccia is composed almost entirely of basaltic to andesitic agglomerates, breccias, pyroclastics, and lava flows, exposed along the north coast of the Gorontalo section. The Pinogo Volcanics constitute a volcanic - sedimentary succession along the south coast. Isolated remnants are present within the central Limboto - Bone rift valley, is thought to have formed in latest Pliocene - Pleistocene [8], [9].

Geologically, Gorontalo is one of the areas in Sulawesi which is rich in precious metal and base metal deposits. The presence of metal precipitation is caused by the position of Gorontalo located in the North Arm of Sulawesi, part of the West Sulawesi Volcanic Arc [5], [9]. Various types of mineralization have been found by previous studies, such as high-, intermediate- and low sulphidation epithermal $\mathrm{Au}-\mathrm{Ag}$, intrusion-related base metal-Au, porphyry $\mathrm{Cu}-\mathrm{Au} \pm \mathrm{Mo}$, sediment hosted-Au, breccia-hosted base metal-Au, volcanogenic massive sulphide $\mathrm{Cu}-\mathrm{Pb}-\mathrm{Zn}$ and skarn $\mathrm{Fe} \pm \mathrm{Au}$ [7], [10], [11].

The study area is situated in Buladu village, East Sumalata Regency, which geologically included in the Tertiary-Pliocene Wobudu Breccia (Tpwv) of Tilamuta Sheet (Fig.1). The Wobudu Breccia consists of volcanic breccia, agglomerate, tuff and lapilli tuff which is intermediate to basaltic in composition, and Early Pliocene in age (about 3.2 to 1.8 million years ago) [3]. Based on the regional study, mineralization type in Sumalata area is intrusion-related base metal-Au [5].

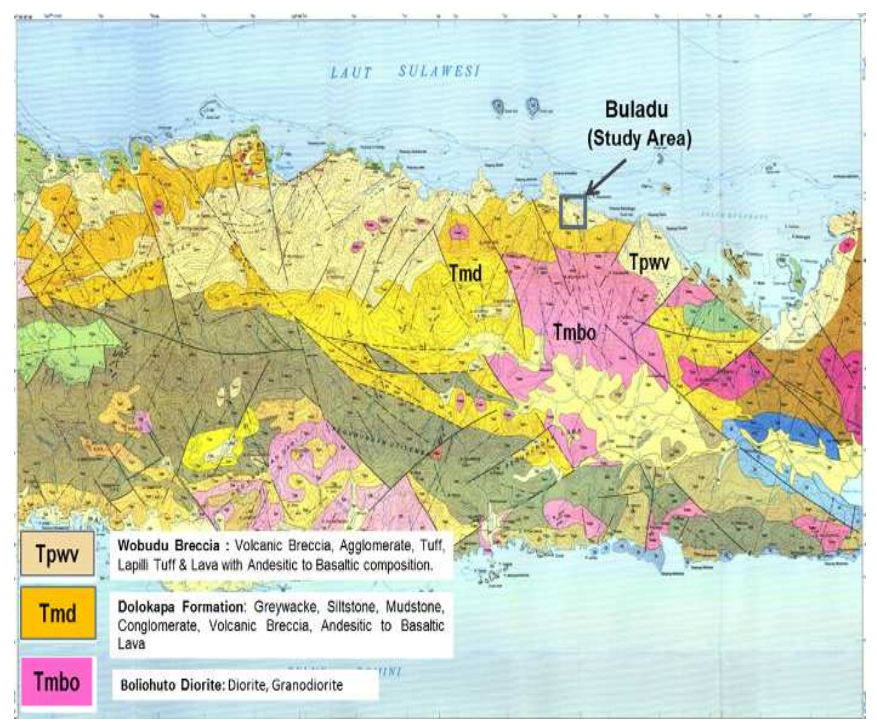

Fig. 1. Location of Buladu area in Geological Map of the Tilamuta Sheet, Sulawesi [modified after [2]

This paper describes a recent study of the mineralization in Buladu area which focused on its associated hydrothermal alteration mineralogy, based on field investigation, microscopic study, and X-ray diffraction (XRD) analysis on altered rock samples.

\section{MATERIAL AND METHOD}

\section{A. Sample Collection and Preparation}

During fieldwork, rock and mineralization sampling was conducted in four methods, random and representative sampling, selected sampling, channel sampling, and systematic sampling. The first method was mainly performed during geological mapping, where samples collected randomly and representatively, based on lithological variation and outcrops availability.

Sampling was conducted at the surface of the fresh rock (unaltered), altered rocks, and rock or mineral that fills the fractures (vein). Unaltered rocks were collected and analyzed to determine background value for various elements in the principles type of rocks. Care was taken to select a representative sample that precisely determine the type of intrusive rocks and host rocks of mineralization. Nearly all of the analytical value is from the altered rocks and are considered to be the measure of a number of elements added during hydrothermal alteration.

Mineralogical analyses include petrography and X-ray Diffraction (XRD). These analyses were performed for studies of rocks and minerals alteration. For petrography, sample preparations in thin sections, as well as their microscopic observation, were conducted at the Laboratory of Optical Mineralogy, Department of Geological Engineering, Faculty of Engineering, Hasanuddin University. For the XRD, sample preparation and analysis using RigakuMultiflex machine were performed at the Laboratory of Economic Geology, Akita University, Japan.

Thin section preparation begins with cuts into the slab of rock samples in size with a glass slide. Slab gradually smoothed using carborundum grit 120, 320, and 800 . Furthermore, slab placed on a glass slide using Canada balsam with refraction index $1.50-1.54$. Cleaned by using the alcohol afterward dry it on a hot plate with temperature of $75^{\circ} \mathrm{C}$ for 12 hours. Slab smoothed returned with aluminium oxide grit 1000, 2000 and 3000 .

In general, altered rock changes shape into a smooth-sized mineral such as clay minerals. X-ray powder diffraction (XRD) is an analytical technique primarily used for identification of phase crystallite of clay minerals. Sample preparation for XRD analysis begins with the sample crushed using agate mortar until a particle size between 2550 microns. Press samples on the sample holder and then scanned by the machine diffractometer.

\section{B. Petrographic Analysis}

The petrographic analysis aims to identify the rockforming minerals and hydrothermal alteration minerals based on their optical properties. Rock types are classified based on the abundance of primary mineral that is determined in thin section. The polarization microscopes are used to determine the optical properties of minerals divided into two parts, that is refracted polarization microscope and the reflective polarization microscope. The refracted polarization microscope using reflected light is used to identify the optical properties of translucent minerals or 
rocks, having slice $0.03 \mathrm{~mm}$ thick. While the type of reflective polarization microscope is used to observe minerals or rocks that are opaque. Ready-to-use microscopes must satisfy the main requirements such as the rays that get into the field of view must be equally distributed, in a centralized condition and the polarized vibration direction must be parallel to one of the cross-section.

\section{XRD Analysis}

Powdered altered rock or clay mineral samples were scanned using a Rigaku-Multiflex X-ray diffractometer, with operating conditions as follow: $\mathrm{CuK} \alpha$-radiation, voltage 30 $\mathrm{KV}$, and current $16 \mathrm{~mA}$. Diffraction patterns were recorded by scanning at 2 -theta between $2^{\circ}$ to $65^{\circ}$. The data obtained is the intensity at a given angle. To identify mineral species were further analyzed using PDX-2 program issued by American Mineralogist Crystal Structure Database (AMCSD) combined with Impact Match! version-2 software.

\section{RESULT AND DISCUSSION}

\section{A. Lithology}

Locally, the study area is arranged by sedimentary, volcanic, and intrusive rocks, which from older to younger are as follow: sandstone, basaltic-andesitic volcanic breccia, granodiorite, and alluvium (Fig. 2).

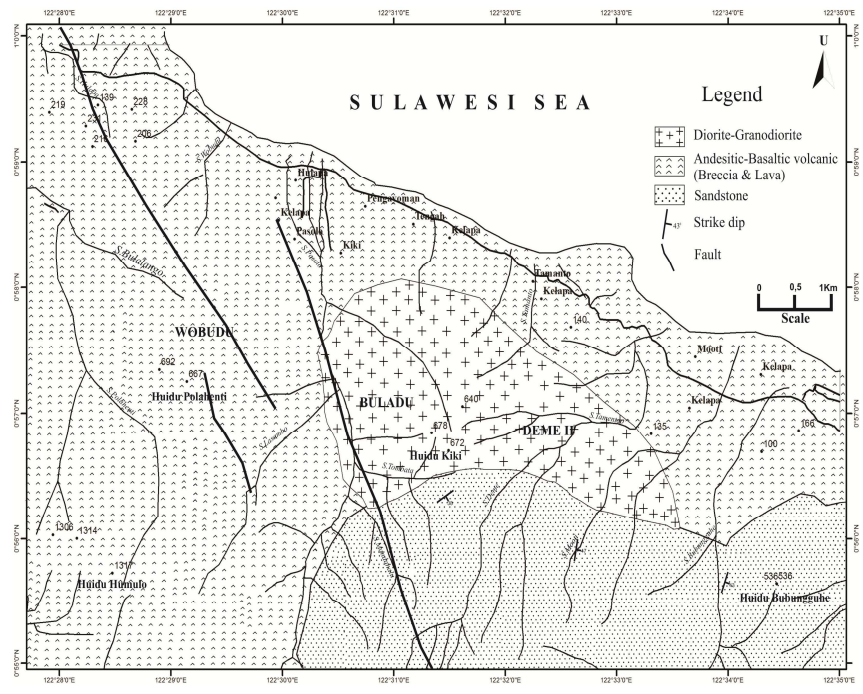

Fig. 2 Geological map of Buladu area

Sandstone, distributed in the south-eastern part of the study area. Outcrop sandstone in the Lasombo river is white if weathered grey, strike, and dip is $\mathrm{N} 215^{\circ} \mathrm{E} / 30^{\circ}$. In general, sandstones in the study area are medium to coarse and angular to sub-angular grains. The mineral composition consists of quartz, feldspar, and clay named felspathic wacke. These sedimentary units are members of the Dolokapa volcano-sedimentary formations Late Miocene age based on an assemblage of foraminifera [12]. Above these rocks, unconformity andesitic-basaltic volcanic breccia and is intruded by granodiorite rocks as exposed in the river Mandawalu

Basaltic-andesites volcanic breccia with andesite lava, basalt lava, lapilli tuff, thin aplite dike and basalt dike distributed broadly in the central and western part of the study area. Lapilli tuff composed of basaltic andesite pyroclastic subangular in a matrix containing plagioclase, which is partially oxidized (Fig. 3a). Lava basalt and andesite that made up a relative thin sequent in the volcanic breccia that is characterized by a darker gray and black color, resistant and locally vesicular (Fig. 3b). The lava member of this unit is the main host rock of the mineralization in the area; these are the members of Wobudu Breccia which is Pliocene in age [3].

Indications of faults found in rock fragments the volcanic breccia, beside the veins, are slickensides. Measurements in the field resulted in general trends of $\mathrm{N} 312^{\circ} \mathrm{E}$ for the slickensides. Some of the quartz veins are distributed in the similar directions to the dikes, and some in different directions, with the general trends of $\mathrm{N} 144^{\circ} \mathrm{E} / 59^{\circ}$ (Fig.3d).

Outcrops of breccias are cross-cut by some basalt dikes of various sizes are trending $\mathrm{N} 272^{\circ} \mathrm{E} / 32^{\circ}-\mathrm{N} 345^{\circ} \mathrm{E} / 293^{\circ}$ (Fig. $3 \mathrm{c}$ ). Occasionally aplite (Fig. $3 \mathrm{~g}$ ) is present in within basaltandesite breccia and representing a remarkable late stage magmatic. Most plutons have many phases with a variety of mineral composition [13]. The aplite thus interpreted the final phase of the granodiorite intrusion on the rock breccia (Fig. 3f).
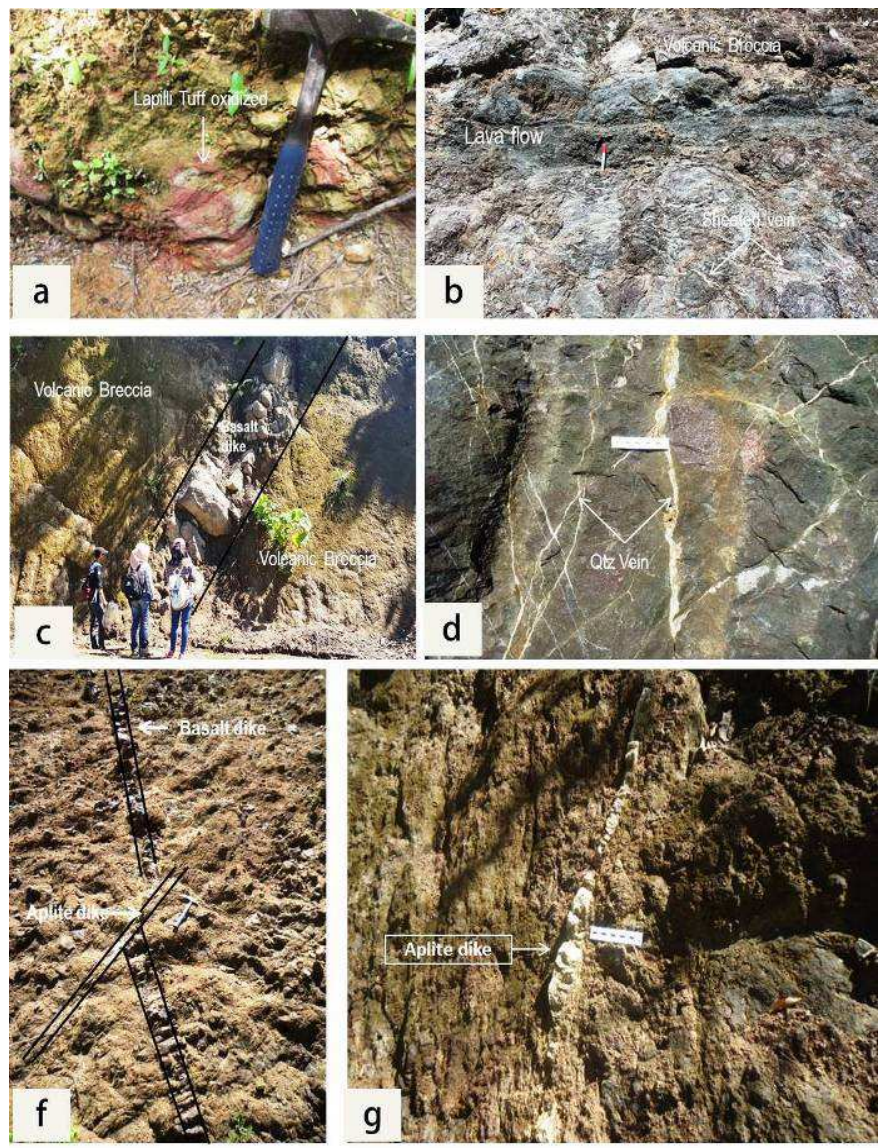

Fig. 3 Outcrop photographs of lithology in the study area: a. lapilli tuff oxidized; b. thin sequent of lava basalt in volcanic breccia; c. a basaltic dike cutting across the volcanic breccia; d. quartz vein in the form of a stockwork structure in andesitic breccia; $f$. the last stage of very thin aplite dike cut across basalt dike; g. aplite dike finely textured granitic composition.

Generally, the whole volcanic breccia, basalt dikes, and veins are intensively weathered. Weathering resulted in the bond between fragments, and the matrix becomes weak and 
some of them regardless of the rock mass. The weathering of rock fragments formed concentric spherical due to the dominance of the mineral feldspar is undergoing a process of hydrolysis, where the cations in the mineral structure were replaced by hydrogen.

The basaltic-andesitic volcanic breccia is composed of igneous rock fragments of basalt and andesite. The rock fragments are generally angular with 10 to $60 \mathrm{~cm}$ size, while the matrices which generally composed of the similar rock types are 1 to $3 \mathrm{~cm}$ in size. The petrographic study showed that andesite fragments of the volcanic breccia have a porphyritic texture and composed by subhedral plagioclase (30 to $35 \%$ ), subhedral to anhedral orthoclase (15 to $20 \%$ ), and anhedral pyroxene (5 to $10 \%$ ) which are distributed in crystalline and glassy groundmass (Fig. 4a). Some of the andesite fragments showed flow texture of plagioclase microlite and volcanic glass. Phenocrysts in basalt fragment consist of subhedral plagioclase (30 to 50\%), anhedral pyroxene (10 to $15 \%$ ), and anhedral olivine (5 to $10 \%$ ), the groundmass comprises approximately $50 \%$ of the rock by volume and is dominated plagioclase laths $(<0.01 \mathrm{~mm}$ in size $)$ and equant pyroxenes with opaques (Fig. 4b). Under microscopic basaltic-andesites lava showed porphyritic finegrained dominated by phenocrysts of plagioclase (70 to $80 \%$ ), augite (5 to $10 \%$ ) minor olivine and opaque minerals within a microcrystalline groundmass. Plagioclase phenocrysts are present as euhedral to subhedral laths $0.5-1$ $\mathrm{mm}$ in length and have well developed Carlsbad twinning. Often plagioclase phenocrysts are short and stubby in some sample. Augite occurs as subhedral to anhedral prismatic 0.2 to $0.5 \mathrm{~mm}$ in length. Olivines are present as rounded anhedral crystals $0.25 \mathrm{~mm}$ in size (Fig. 4c).

Some of the rock fragments showing 0.5 to $5 \mathrm{~cm}$ diameter holes, which is interpreted as vesicular, where gasses released when the hot igneous rock fragments met the atmosphere at the time of the explosion. Another interpretation is the holes are the former place of pyrite grains that have broken and released out by intensive weathering; this is indicated by the dominant cubic shape of the holes. Abundant of pyrite were also found in and the margins of the quartz veins.

Granodiorite intrusive with diorite distributed locally in the central part intruded the Wobudu Breccia members (volcanic breccia and lava) and interpreted as the source of hydrothermal fluid responsible for the mineralization in the study area, the intrusion took place during Pliocene [6]. The granodiorite showed intergranular texture and composed of mineral crystals size of 1.0 to $3.2 \mathrm{~mm}$ (Fig. $4 \mathrm{~d}$ ). As the mineral composition comprised of subhedral plagioclase (30 to $40 \%$ ), subhedral orthoclase (10 to $20 \%$ ), subhedral to anhedral quartz (10 to 20\%) and mafic minerals mainly hornblende (5 to $10 \%$ ) (Fig. 4e). Granodiorite and diorite both have a granitic texture, one and the other distinguished by the percentage composition of quartz and feldspar. Diorites are characteristic by andesine plagioclase (40 to $60 \%$ ) orthoclase (10 to $15 \%)$, hornblende (10 to $15 \%)$ and quartz (5\%) (Fig. 4f).

Basaltic andesites are intermediate between basalts and andesites and are often plagioclase-rich, the characteristics of calc-alkaline rocks [14] like most rock associated with the mineralization in northern Sulawesi [5], [11], and North
China [14]. Association of diorite-granodiorite intrusive rocks, basalt dike, interlayer basaltic andesitic volcanic breccia with andesite lava and hydrothermally altered rocks are the characteristics of central facies volcanic [15].
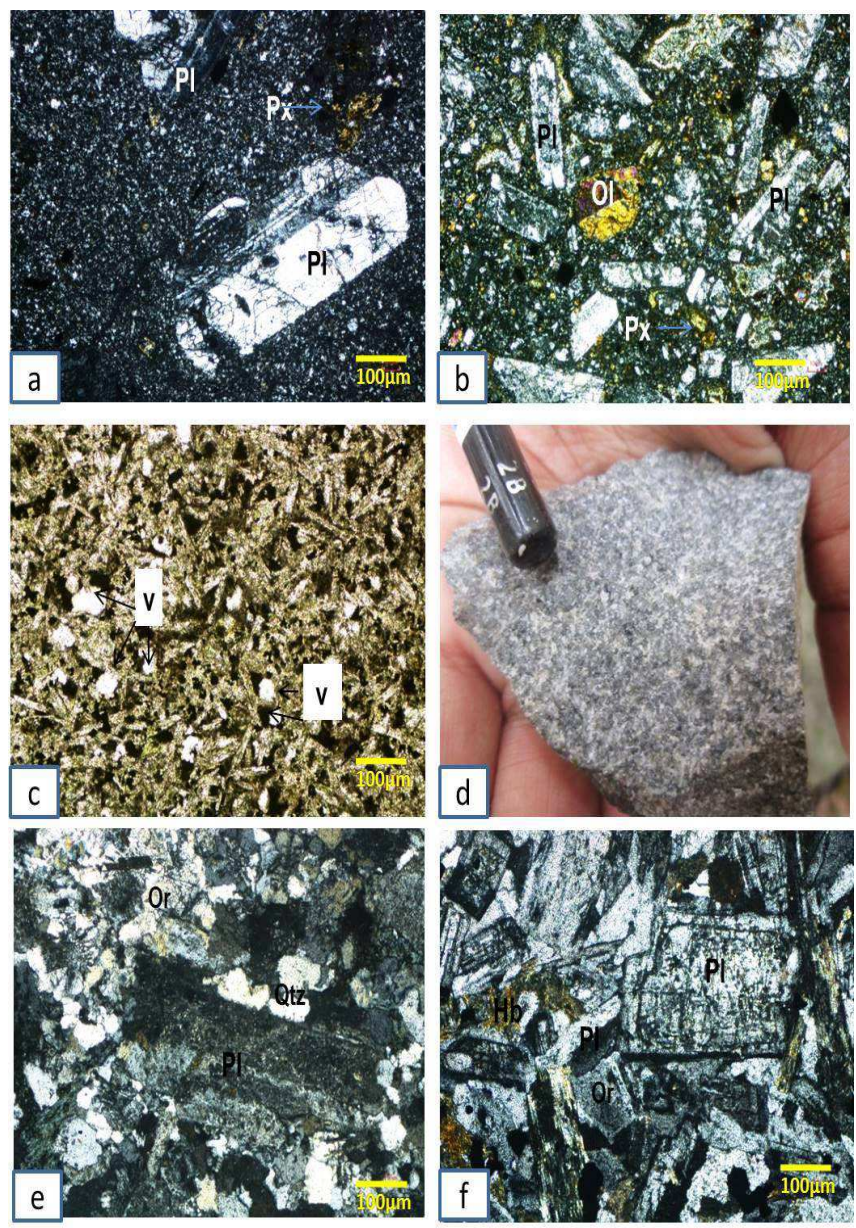

Fig. 4 Photomicrograph of basaltic-andesites volcanic and granodiorite intrusive: a) pilotaxitic texture or trachytic groundmass in andesite with phenocrysts of zonal plagioclase; b) olivine and zonal plagioclase phenocryst in microlithic groundmass; c) intergranular texture in basalt and irregular vesicle; d) hand specimen of granodiorite that granular coarsegrained holocrystalline; e) granodiorite holocrystalline comprises of tabular lath plagioclase with intergranular anhedral quartz; f) diorite dominated by subhedral tabular plagioclase and less untwinned orthoclase and anhedral quartz within the intergranular area.

\section{B. Hydrothermal Alteration}

As mentioned, the study area is mainly arranged by intermediate to mafic volcanic rocks. The rocks are generally mineralized which characterized by the occurrence of pyrite, chalcopyrite, malachite and hematite, and in some places carbonate and quartz veins. The dominant rock types are andesite to porphyry andesite. These rocks are overlain by Miocene volcanic rock of tuff. These volcanic rocks are members of Wobudu Breccia Formation. Granodiorite intrusive and host rocks are affected by intensive as well as extensive alteration.

Alterations took place during several stages with changing temperature, pressure and composition properties of fluids, resulting in overprinting of earlier mineral associations. Resulting assemblages of secondary minerals are complex and mineral associations characteristic of individual alteration types. Derived from the environment of fresh 
rocks outside of the magmatic-hydrothermal system the following imperative alteration zones could be recognized an outer zone of chloritic alteration and the inner zone of argillic alteration (Fig. 5). Propylitic alteration zones scattered basaltic-andesitic volcanic breccia and on the outer diorite-granodiorite intrusion. Whereas argillic alteration zones spread on basaltic-andesitic volcanic breccia.

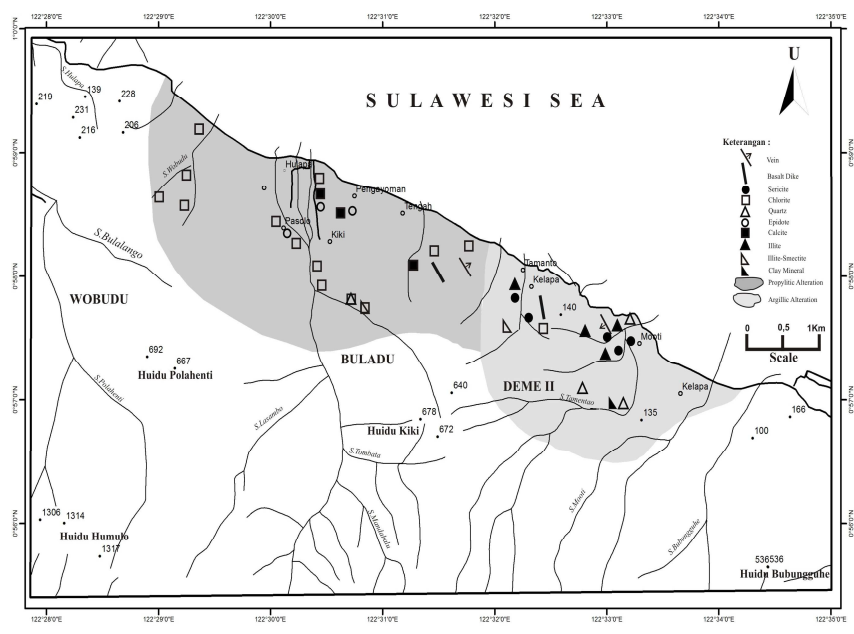

Fig. 5 Alteration map at Buladu area

At locations that relatively distance to the mineralization, outcrops of propylitic alteration were found in the study area. As can be seen in Figure 6a, an indication of the propylitic alteration occurred in altered andesitic lava which is shown by the greenish color of the outcrop. The greenish colour represents chlorite and epidote, the key minerals of propylitic alteration [16]. Under the microscope, the presence of chlorite, epidote, and carbonate that selectively altered or replaced the groundmass pyroxene was observed in thin section (Fig. 6b).

In the granodiorite rocks, fine sized plagioclase altered by chlorite, epidote, and sericite, whereas the large plagioclase altered by dominance sericite (Fig. 6c). Hornblende minerals at diorite, which intensive altered by chlorite and epidote, that the identification of primary hornblende resulting in relict of cleavage and shape.

In hydrothermal mineralizations, the propylitic alteration has generally occurred distal to the mineralization [17], [18], [19]. Propylitic alteration normally develops at depth and marks the outer boundary of many hydrothermal deposit styles [19]. The classic mineral assemblage of propylitic alteration consists of chlorite, epidote, albite, and carbonate [20], [21].

Clay minerals are the most common and dominant hydrothermal alteration minerals that are observed in the study area. Two types of clays were identified from the surface based on XRD analysis that is illite and chlorite. Illite is common clay mineral extensively distributed in this well. It is colorless to brown under the petrographic microscope. It is observed as an alteration product of feldspar. Under XRD analyses, it shows strong peaks of between 2.55 to $10.03 \AA$.

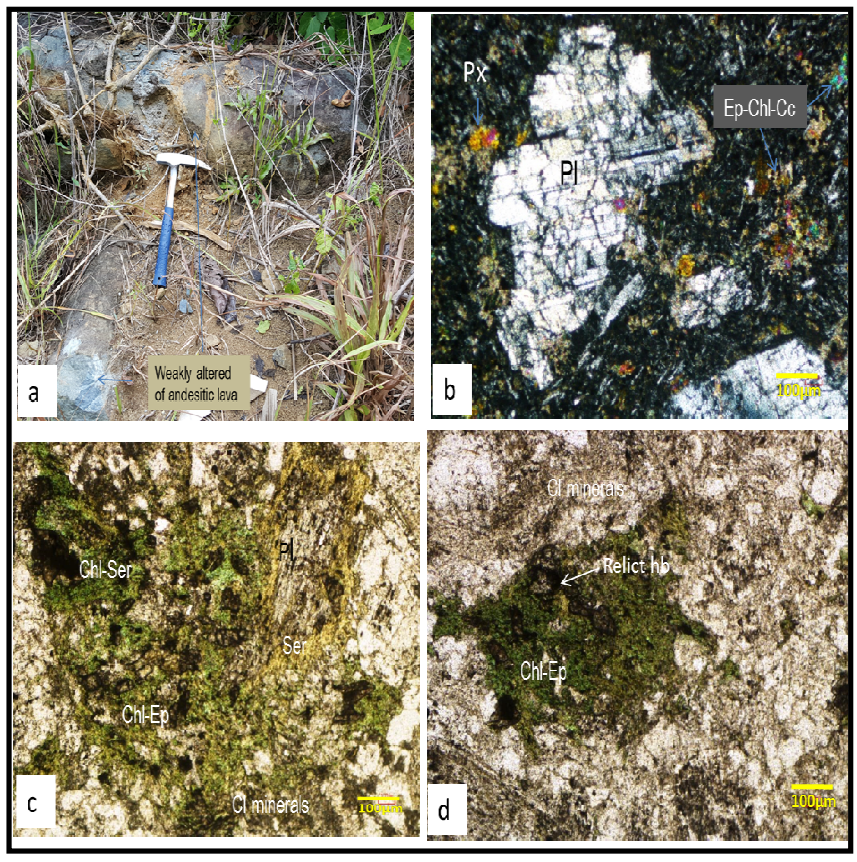

Fig. 6 Indication of propilytic alteration: a) outcrop of andesitic lava which weakly altered indicated by greenish colour; b) photomicrograph of andesitic lava selectively altered by chlorite-epidote-carbonate in groundmass; c) chlorite-sericite-epidote were selectively replaced plagioclase in granodiorite; d) photomicrograph chlorite-epidote were selectively replaced hornblende in diorite.

Chlorite is pale green to dark green in thin sections, it is pale green and occasionally shows anomalous brown color. It is fine to coarse-grained weakly to non-pleochroic and shows low birefringence. XRD analyses of chlorite show conspicuous peaks at 7.0-7.2 $\AA$ and 14.0- 14.5 (Fig.7)

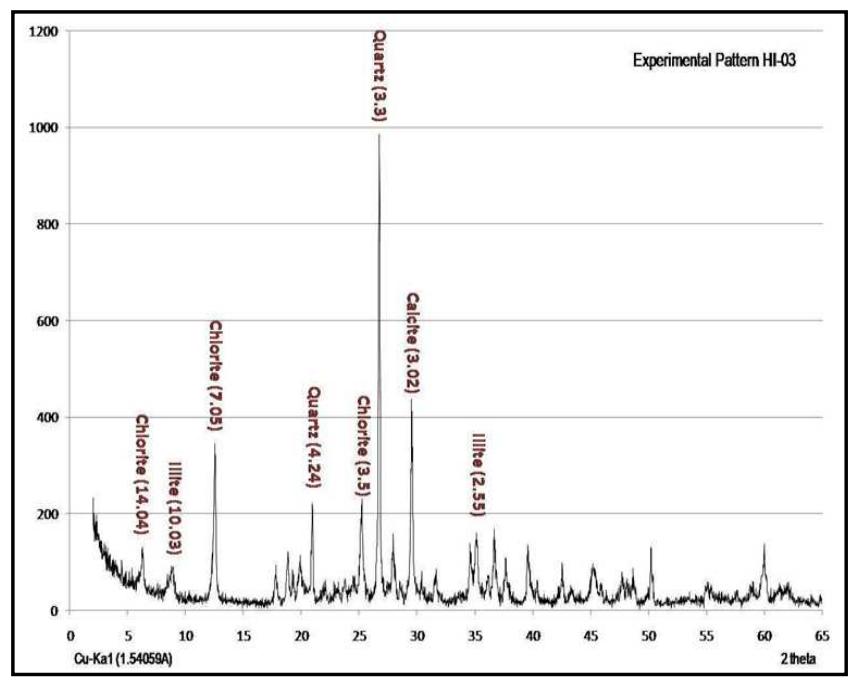

Fig.7 XRD patterns of altered rock samples. Minerals identified include chlorite, quartz, iliite.

Mineral compositions changing in the rocks due to reactions with hydrothermal fluids are broadly distributed in Buladu area. Altered rock fragment basalt and andesite were determined based on its color changing to the green that related to chloritization. Partially alteration processes in rock fragments have formed chlorite, epidote, and sericite, selectively to pervasively. In propylitic alteration, measly of 
epidote minerals are formed so interpreted that the andesite fragments lack ferromagnesian minerals, or hydrothermal solutions do not contain iron or magnesium sufficient for epidote mineral formation [22], [23].

The rock samples studied in argillic alteration zone which dominated by illite, sericite, quartz, and a little chlorite and carbonate. The alteration showed characteristics of pervasive to selective alteration, where illite and quartz totally replaced groundmass, whereas chlorite and clay minerals were selectively altered plagioclase phenocrysts (Fig. 8a). Vuggy silica is also present but is not well-developed (Fig. 8b). It grades outwards through sericite alteration, consisting predominantly of illite and quartz, it is notable that the argillic alteration system is barren and not directly associated with gold or base-metal mineralization [23]. Under the microscope, carbonate was observed in veinlets and some together with sericite and illite replaced groundmass (Figure 8c).

Pervasive alterations have changed phenocrysts and groundmasses in andesite and basalt. Minerals illite, chlorite and carbonate have totally altered the whole crystals of the fresh rocks causing difficult to identify the primary minerals based on their crystals (Figure $8 \mathrm{a}$ and $8 \mathrm{~d}$ ). In moderately altered rocks, the alteration is selective, only feldspar altered to sericite and clay (Figure $8 b$ ).
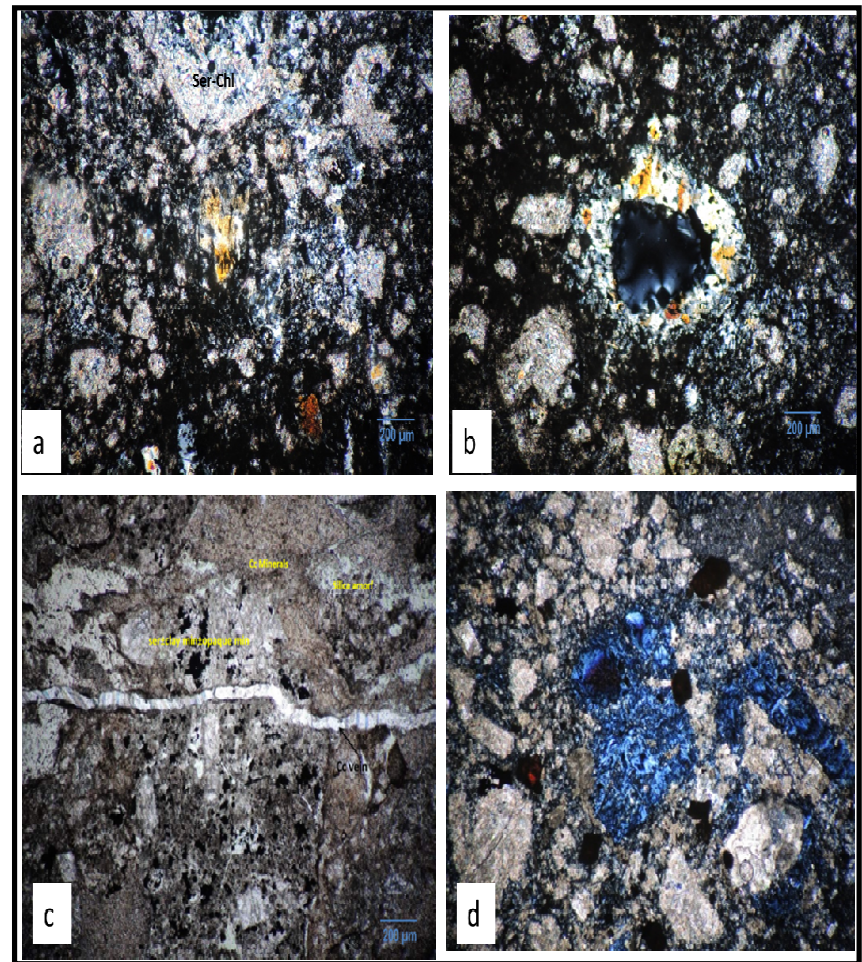

Fig. 8. Photomicrograph of argillic alteration (a) Relict of feldspar minerals replaced by sericite, chlorite, and clay mineral; (b) Relict of feldspar minerals replaced by sericite, and chlorite; Vug is surrounded by quartz (vuggy silica texture); Groundmass mostly replaced by clay and opaque (c) Vein of carbonate was formed as fluid entered an open space fracture during alteration; (d) Whole primary minerals have been replaced by clay, chlorite, sericite, carbonate and opaque.

\section{Gangue Mineralogy}

Gangue minerals associated with the mineralization in the study area are mostly quartz and less carbonate. These are two common and typical gangues of vein type mineralizations, particularly epithermal [24]. In the outcrops, quartz veins found in 1 to $5 \mathrm{~cm}$ thickness and $\mathrm{N} 125^{\circ} \mathrm{E}$ to $\mathrm{N}$ $263^{\circ} \mathrm{E}$ strike. The quartz textures are crustiform banded, comb and crystalline (Fig. 9), while in carbonate veins, lattice bladed texture occurred. The carbonate veins are light grey and generally thinner than the quartz veins, the average thickness is 0.5 to $1 \mathrm{~cm}$. Some of the fractures were filled by quartz and carbonate forming veins and veinlets. General trends of the veins and veinlets are $\mathrm{N} 345^{\circ} \mathrm{E}$ and $\mathrm{N} 293^{\circ} \mathrm{E}$, and in places, they also occurred as vein stockwork (Fig. 3c).

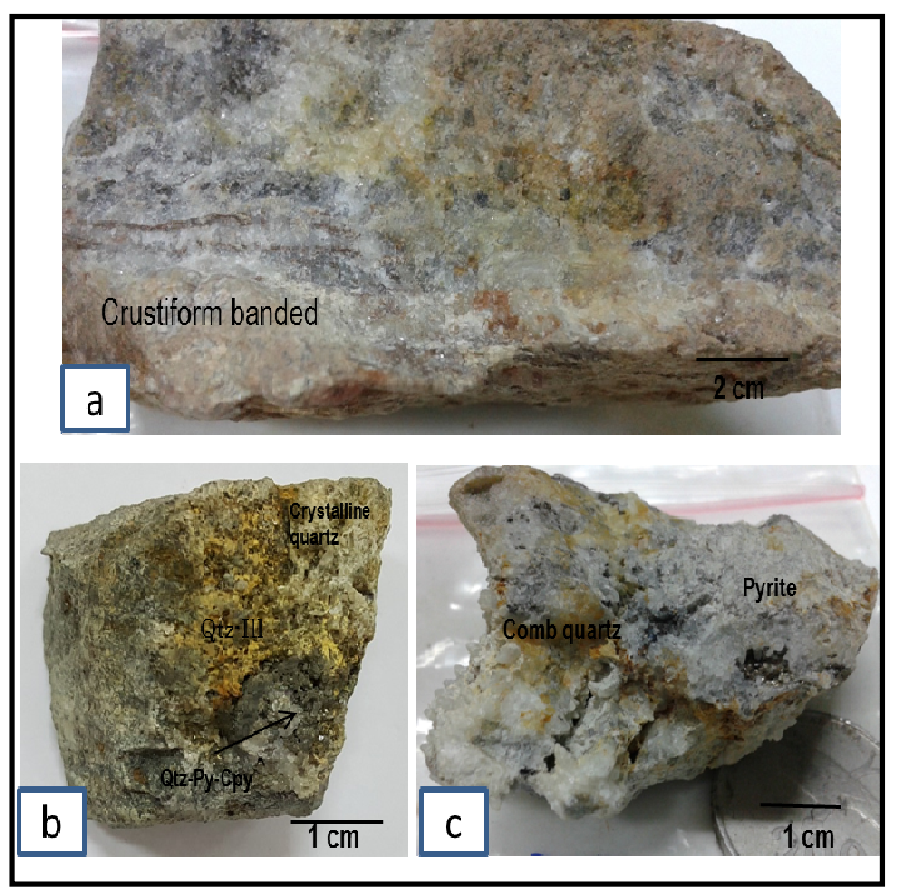

Fig. 9 Quartz vein textures; a) Crustiform banded, b) crystalline and c) Comb.

\section{CONCLUSIONS}

Host rocks of the mineralization are flow-volcanic breccia of the Miocene Wobudu Breccia, which composed of igneous rock fragments of basalt, andesite, and granodiorite. Mineralization in the study area mostly occurred in the form of veins with quartz and carbonate as the main gangues. Quartz in veins is characterized by crystalline, vuggy and fine banded textures, while carbonate in veins is characterized by lattice bladed texture. The hydrothermal alteration was zoned from outer (distal) propylitic to inner (proximal) argillic. The propylitic were characterized by selective alteration with dominant mineral assemblages of chlorite, epidote, and carbonate; while the argillic were mainly characterized by pervasive alteration with the main mineral assemblages of illite, chlorite, and quartz. Both the mineralization and hydrothermal alteration characteristics suggested that the mineralization in the study area is the epithermal type.

\section{ACKNOWLEDGMENT}

The authors thank the Directorate of Higher Education, Department of National Education, Indonesia for the "Higher Education Superior Research Grant" through Centre of Research and Community Services Hasanuddin 
University. Thanks are also dedicated to the Local Government of Gorontalo Province and to PT. Makale Toraja Mining for the permission to collect field data in Buladu area.

\section{REFERENCES}

[1] R. Hall and M. E. J. Wilson, "Neogene sutures in Eastern Indonesia", Journal of Asian Earth Sciences 18, 781-808, 2000.

[2] R. Hall, "Indonesian tectonics: subduction, extension, provenance and more", Proceedings $38^{t^{\text {th }}}$ Annual Convention of the Indonesian Petroleum Association, Jakarta, Indonesia, 2014.

[3] S. Bachri, Sukido and N. Ratman, Geological map of the Tilamuta Sheet, Sulawesi, Geological Research and Development Centre, Bandung, Indonesia, 1993.

[4] S. Zahirovic, M. Seton, and R. D. Müller, "The Cretaceous and Cenozoic tectonic evolution of Southeast Asia", Solid Earth, 5, 227273, 2014.

[5] T. M. van Leeuwen and P. E. Pieters, "Mineral deposits of Sulawesi", Proceedings of the Sulawesi mineral resources, MGEI - IAGI, Manado, North Sulawesi, Indonesia, 2011.

[6] M. Elburg and J. Foden, "Geochemical response to varying tectonic settings: an example from Southern Sulawesi (Indonesia)", Geochimica et Cosmochimica Acta 63, 1155-1172, 1999.

[7] T. M. van Leeuwen and Muhardjo, "Stratigraphy and tectonic setting of the Cretaceous and Paleogene volcanic sedimentary successions in Northwest Sulawesi, Indonesia: implications for the Cenozoic evolution of Western and Northern Sulawesi", Journal of Asian Earth Science 25, 481-511, 2005.

[8] D. F. Pearson and M. M. Caira, "The geology and metallogeny of Central North Sulawesi", Proceedings $4^{\text {th }}$ PARCIM Congress, Australian Institute of Mining and Metallurgy, 311 - 326, 1999

[9] I. Kavalieris, T. M. van Leeuwen and M. Wilson, "Geological setting and styles of mineralization, north arm of Sulawesi, Indonesia", Journal of Southeast Asian Earth Sciences, Vol. 7, No. 2/3, 113-129, 1992.

[10] J. C. Carlile, S. Digdowirogo, and K. Darius, "Geological setting, characteristics and regional exploration for gold in the volcanic arcs of North Sulawesi, Indonesia", Journal of Geochemical Exploration, 35, 105-140, 1990.

[11] M. Yamamoto, A. Maulana, K. Yonezu, K. Watanabe, and A. Subehan, "Geochemistry and Mineralization Characteristic of Sungai Mak Deposit in Gorontalo, Northern Sulawesi, Indonesia", International Journal of Engineering and Science Applications, Vol. 2, Issue 2, 2015

[12] J. Hennig, E. Advokaat, A. Rudyawan and R. Hall, "Large sediment accumulation and major subsidence offshore; rapid uplift on land; consequences of extension of Gorontalo Bay and northern Sulawesi”, Proceedings of Indonesia Petroleum Association Vol. 38, Jakarta, 304-313, 2014.
[13] C. J. R Hart, and R. J. Goldfarb, "Distinguishing intrusion-related from orogenic gold systems", Proceedings of New Zealand Minerals Conference: Realising New Zealand's Mineral Potential, Australasian Institute of Mining and Metallurgy, 125-133, 2005

[14] F.-J. Nie, S.-H. Jiang and Y. Liu, "Intrusion-Related Gold Deposits of North China Craton, People's Republic of China", Resource Geology, Vol. 54, No. 3, 299-324, 2004

[15] L. F. Vassallo, J. J. Aranda-Gómez and J. G. Solorio-Munguía, "Hydrothermal alteration of volcanic rocks hosting the Late Jurassic Early Cretaceous San Nicolás VMS deposit, southern Zacatecas, Mexico", Revista Mexicana de Ciencias Geológicas, Vol. 32, No. 2, 254-272, 2015.

[16] G. J. Corbett and T. M Leach, "Southwest Pacific gold-copper systems: Structure, alteration and mineralization": Special Publication 6, Society of Economic Geologists, 238 p., 1998.

[17] M. T. Einaudi, J. W. Hedenquist and E. E. Inan, Sulfidation state of hydrothermal fluids: The porphyry-epithermal transition and beyond, in Simmons, S.F, and Graham, I.J., eds., Volcanic, geothermal and ore-forming fluids: Rulers and witnesses of processes within the Earth: Society of Economic Geologists and Geochemical Society, Special Publication 10, 285-313, 2003.

[18] R. H. Silitoe and J. W. Hedenguist, "Linkages between volcanotectonic settings, ore-fluid compositions, and epithermal precious metal deposits", Special Publication 10, Society of Economic Geologists, 2003.

[19] I. Nur, Sufriadin, S. Widodo, U. R. Irfan, "Metamorphic facies and hydrothermal alteration characteristics of the metamorphic-rock hosted gold at Gunung Botak and Gogorea, Buru island, Indonesia", Proceeding of Celebes International Conference on Earth Science (CISES), University of Halu Oleo, Kendari, Southeast Sulawesi, Indonesia, 68 - 78, 2014.

[20] E. Seedorff, M. D.,Barton, W. J. A Stavast, and D. J. Maher, "Root zones of porphyry systems: Extending the porphyry model to depth", Economic Geology, v.103, p. 939-956, 2008

[21] P. C. Voudouris, "Hydrothermal corundum, topaz, diaspore and alunite supergroup minerals in the advanced argillic alteration lithocap of the Kassiteres-Sapes porphyry-epithermal system, western Thrace, Greece", Journal of Mineralogy and Geochemistry, Vol. 191, 2, 117 - 136, 2014.

[22] B. P. Murray, and C. J. Busby, "Epithermal mineralization controlled by synextensional magmatism in the Guazapares Mining District of the Sierra Madre Occidental silicic large igneous province, Mexico", Journal of South American Earth Sciences, 58, 1-18, 2015.

[23] M. L. Djouka-Fonkwé, K. Kyser, A. H. Clark, E. Urqueta, C. J. Oates, and C. Ihlenfeld, "Recognizing Propylitic Alteration Associated with Porphyry Cu-Mo Deposits in Lower Greenschist Facies Metamorphic Terrain of the Collahuasi District, Northern Chile - Implications of Petrographic and Carbon Isotope Relationships", Economic Geology, Vol. 107, 1457-1478, 2012.

[24] J. W. Hedenquist, A. Arribas, and E. Gonzalez-Urien, "Exploration for epithermal gold deposits": Reviews in Economic Geology, v. 13, $245-277,2000$ 